\title{
30 years later: Social Representations about AIDS and sexual practices of rural towns residents
}

\author{
30 anos depois: Representações Sociais acerca da Aids e \\ práticas sexuais de residentes de cidades rurais \\ 30 años después: Representaciones Sociales acerca del Sida y \\ prácticas sexuales de residentes en ciudades rurales.
}

Francisca Marina de Souza Freire Furtado¹, José Anderson Galdino Santos², Loredanna Stedile ${ }^{3}$, Eunice Araújo ${ }^{4}$, Ana Alayde Werba Saldanha ${ }^{5}$, Josevânia da Silva ${ }^{6}$

1,2,3,4,5 Universidade Federal da Paraíba-UFPB, João Pessoa, Paraíba, Brazil.

${ }^{6}$ Universidade Estadual da Paraíba (UEPB), Campina Grande, Paraíba, Brazil.

\section{ABSTRACT}

In the 30 years of the AIDS pandemic in Brazil, it is recognized the HIV virus internalization of the phenomenon as a challenge to care and current health policies. In this sense, it aimed to verify sex practices and social representations that rural towns residents have about the disease. Attended by 789 people, men and women, between 18 and 90 years old, residents in 41 towns with fewer than 11,000 inhabitants in the state of Paraiba / Brazil. Data were collected by a questionnaire and the free association of words test. The results showed low concern about disease, perception of invulnerability to HIV infection and not using condoms during sexual intercourse, and confidence in the major reason related partner. Also showed endure derogatory and stereotypical representations, revealing that still persist in rural areas, beliefs and representations concerning the beginning of the epidemic. From these findings, it is possible to point out deficiencies in the care provided by the health services in these localities, which may result in increased vulnerability of this population to diseases, so there is the need to intensify information campaigns and intervention.

\section{DESCRIPTORS}

Health vulnerability; rural population; acquired immunodeficiency syndrome.
Correspondence Addressed to:

Francisca Marina de Souza Freire Furtado

Universidade Federal da Paraíba, Centro

de Ciências Humanas e Letras - Programa

de Pós-Graduação em Psicologia Social -

Departamento de Psicologia, Ambiente dos professores, Sala 12

CEP 58051-900 - João Pessoa, PB, Brazil

marinasfreire@hotmail.com
Received: $26 / 03 / 2015$

Approved: 14/11/2015 


\section{INTRODUCTION}

Since its emergence in the 1980s, Aids (Acquired Immunodeficiency Syndrome) has been a major worldwide public health concern due to its harmful, heterogeneous and unstable characteristics ${ }^{(1-2)}$. Despite the advances in treatment due to the use of antiretroviral therapies, Aids remains the fifth leading cause of mortality among adults and the first among young women ${ }^{(3)}$. In Latin American countries and the Caribbean, unprotected sex remains the primary route of infection by the HIV virus, with the highest prevalence in men who have sex with men and transgender women ${ }^{(3-4)}$.

According to the latest epidemiological bulletin of the Brazilian Ministry of Health ${ }^{(5)}$, the detection rate of the disease has increased by $2 \%$ in Brazil, significantly distributed among Brazilian regions and age ranges, showing a trend towards increased infection rates in poorer regions such as the North-Northeast, and among the young and the elderly. It is estimated that $87 \%$ of Brazilian municipalities have had at least one Aids case and that currently about 718,000 people live with HIV in the country ${ }^{(3)}$. In this scenario, phenomena such as feminization, impoverishment and dissemination of the epidemic in the rural areas have gained increasing attention from scholars, highlighting the importance of socioeconomic, regional and cultural aspects, gender, race/ethnicity, and the lack of structural and human resources in health as elements of vulnerability to HIV/Aids ${ }^{(6-8)}$. In terms of vulnerability, one seeks to understand how individuals and social groups "are exposed to a given serious health hazard considering wholes consisting of pragmatically constructed syntheses based on three analytical dimensions (...) namely individual, social and programmatic dimensions"(9).

Vulnerability analysis includes the participation of various social actors and contexts, deconstructing previous strategies of blaming the subject for his illness. Thus, among the aspects of the first dimension, there is the degree and quality of information that the subjects have, and how they understand and incorporate this information into their daily practices. The social dimension comprises the contextual aspects that include individuals, groups and the collective, involving aspects related to religious beliefs, gender relationships, economics, etc. The last dimension concerns how institutions and public policies, especially health, social welfare, education, justice and culture, have collaborated to reduce, reproduce or enhance conditions of vulnerability of individuals and communities in their contexts ${ }^{(10)}$. Thus, based on the conceptual framework of vulnerability, and the inseparability of its dimensions, it is possible to contextualize vulnerability to HIV/Aids in the context of rural cities, given the change in the profile of the epidemic in the last three decades.

Considering the phenomenon of dissemination of the epidemic in the rural areas of Brazil, although HIV-positive people still remain concentrated in large cities, recent survey studies point to a significant growth in medium-sized cities, highlighting inequalities in access to services and low resoluteness of smaller municipalities in terms of care, treatment and management of the disease ${ }^{(11-12)}$. In small municipalities, although the occurrence of the disease is still regarded as irregular and of small magnitude - an average of 4.7 cases per 100,000 inhabitants ${ }^{(11)}$ - one cannot fail to consider factors such as poverty, low education and income - which remain as characteristics of a great part of the population of small municipalities. These facts, when linked to health care service shortages, can contribute to restrictions in terms of the information about Aids and safe sex practices within this population, thereby putting them in situations of increasing vulnerability and risk. Researchers emphasize heterosexual transmission, which is the main form of transmission in these locations, which places women in more vulnerable situations, because of gender inequalities ${ }^{(11-12)}$.

A study performed with teenagers from Paraíba to evaluate sexual behavior and care practices ${ }^{(13)}$ showed that, in the rural context, this population had little information about STD/Aids and generally did not use condoms in stable sexual relationships; many teenagers attribute HIV infection to "a thing of destiny." Similar results were also observed in a study with adolescents from two cities in a northeastern, semi-arid region ${ }^{(14)}$. These findings are related in some way with programmatic vulnerability, and contribute to the way people understand and give meaning to health and disease processes, mediating their sexual practices and coping and care strategies.

In contemporary times, efforts have been made to establish public policies that foster quality care for people with HIV/Aids, but overcoming inequities and inequalities is a challenge for those who defend life as the right to public goods and citizenship ${ }^{(15)}$. However, populations territorially defined as rural or urban have differences in access to and use of health services, and the rural towns are those with greater challenges.

In addition to the difficulties with access to health services, the socioeconomic aspects and political context hinder the effective implementation of public policies to a greater or lesser extent. In addition, inadequate access to an effective health care system is one of its pillars, followed by supply-related problems and the organization of health services, the difficulty in attracting physicians and other healthcare professionals, in addition to the turnover of these professionals, and the quality of care provided ${ }^{(16)}$. Therefore, health actions often become inaccessible. Moreover, issues related to prevention of STDs/Aids in older people become less of a priority when considering other existing demands.

Given the need for more knowledge about the health-disease process, theoretical and methodological contributions have emerged in several areas. In the field of social psychology, the study of social representations has had an important role in understanding the processes and mechanisms of the construction of social meaning for getting Aids $^{(17-19)}$. Considering this aspect, it is possible to find studies on social representations of Aids in the rural context, demonstrating a concern with this locus of research ${ }^{(18-20)}$. 
However, the results obtained were not promising. These studies showed that representations still remain related to the start of the epidemic, such as contamination only through shared objects and related only to risk groups such as homoaffective people ${ }^{(19)}$. It was also possible to observe feelings of invulnerability in this population, for which $\mathrm{Ai}-$ $\mathrm{ds}$ is "disease of the others" (20).

The scarcity of research aimed at the rural population suggests that the extent of disparities in health, and access to care, in these populations has not been adequately monitored. In the field of HIV/Aids, therefore, the importance of understanding the beliefs, perceptions and representations built and shared by the rural population is recognized, given that this understanding can allow them to build more appropriate interventions and policies with this population. In this sense, this study aimed to investigate sexual and prevention practices and representations that rural town residents have about Aids.

\section{METHOD}

An exploratory and qualitative study was performed in 41 cities with less than 11,000 inhabitants of the state of Paraiba/Brazil. The choice of this research locus was due to the fact that $66 \%$ of the municipalities of Paraiba have this population size. A representative sample of the population was determined using a multistage process, stratified as: 1 ) the four geographical regions of health; 2) the 16 existing health regions in Paraiba; 3 ) at least two municipalities with less than 11,000 inhabitants belonging to each region; and, 4) the inhabitants. Seven hundred eighty-nine people between 18 and 90 years participated in the study, with a mean age of 42 years $(\mathrm{SD}=14.94), 180$ men $(22.8 \%)$ and 608 women $(77.2 \%)$.

After approval by the ethics in research committee, the researchers traveled to the selected municipalities. People were approached in their homes, recreational squares and/ or streets, and invited to participate. The adopted exclusion criteria were: participants under 18 years old, and residents of the city for less than two years. Respecting the required ethical standards, emphasis was placed on the voluntary nature of participation and the confidentiality of information.

First, a sociodemographic questionnaire was administered to characterize the sample, containing items related to sexual behavior and prevention practices, such as the use of condoms during sexual intercourse; difficulties or interruptions in the use of condoms; reasons related to interruption; and perceptions related to concerns about AIDS and the risk of contamination. Thereafter, the technique of free word-association was performed, asking participants to say the first three words or thoughts that came to mind when hearing the word Aids.

The questionnaire data were analyzed using descriptive statistics (frequency distribution, measures of central tendency and dispersion) using the Statistical Package for the Social Sciences software (SPSS) for Windows, version 18. The responses obtained in the free word-association technique were analyzed for their content, following the method of $\operatorname{Bardin}^{(21)}$.

\section{RESULTS}

Most participants were: aged 30 to 59 years, married, farmers, with low levels of education and income, and $\mathrm{Ca}$ tholic. In terms of sexual and preventive practices, most (60\%) reported never having used a condom. Among those who had, most said that they ceased to use them after a certain length of relationship, with confidence in the partner being the main reason.

When asked to assess their concern about Aids on a scale of 0 to 10 points, the mean obtained score was 7.51 (moderate level). However, when assessing the risk of contracting HIV from their sexual practices, the mean score was 2.81 (low level). In response to a complementary question, $85 \%$ of participants responded that they never believed they could have contracted the HIV virus, with only $14.4 \%$ claiming to have had this suspicion.

Regarding the qualitative analysis of data obtained through the free word-association technique, five thematic categories of meanings attributed to HIV/AIDS by the participants were constructed: a) characterization/impression about Aids; b) blame and Judgment; c) conviction imposed by Aids; d) negative feelings about Aids; and, e) positive feelings about Aids.

The first category, characterization/impression about Aids, sought to group words regarding the general knowledge and beliefs about the disease. It first consisted of words that showed negative perceptions about the disease such as: bug, cancer, bad thing, deformation, should not exist, does not like to talk about it, sent by "Satan", changes life, does not wish it for anybody, sad word, and loss of meaning. Later it included perceptions brought about by the biomedical discourse, such as: contagious, chronic, serious illness, blood disease, dangerous disease, heavy disease without cure, fearful disease, pain, STD, venereal disease, immunology, infection. Perceptions related to the form of contagion were expressed, such as: it is not so dangerous, gotten through sex, should avoid it, I cannot have it by touching, no one wants it, sexual intercourse, avoiding approach, does not transmit easily, puncture/cutting, condoms. Perceptions related to the illness consequences were expressed, such as: weight loss, loss of life, requires care, hair falls out, aching, tests, worsens the quality of life, if you don't take care you'll die, motionless, prejudice, bad feeling, psychological help, care early, dependency, relying on drugs, hospitalization, weakness, severe, hospital, impotence, it kills, medication, easily kills. There were also representations of illness related to whether or not treatment was possible, with words such as: incurable, not afraid, normal, there is treatment, common, can live, curable, can fight, prevent, is and is not curable, can be cured, can have health, needs help, prevention, seek health, protect, wanted a cure, there is care service. Finally, there were perceptions denoting a certain lack of knowledge, with words such as: does not believe, does not know, does not exist, does not think anything, does not know what it is, does not know much, knows little.

In the second category, blame and judgment, the grouped words referred to an accountability of the person with Aids for having gotten the disease, blaming her for her 
diagnosis. Also, words were included that demonstrated the judgment made by the respondents about the person with Aids, labeling her a few times and also trying to determine something that, according to their beliefs, justified the diagnosis. The words arising in this category were: careless, "dismantled" (popular expression for a careless person), lack of care, lack of information, lack of prevention, reckless, immoral person, sex without a condom, promiscuous life, very ugly, lack of love, lack of care, lack of prevention, lack of protection, involuntary, irresponsibility, many partners, did not take care of herself, steady partner, prostitution, those with (extramarital) "flings", carelessly, "the person sought it", neglect, disobedience, not prevented, cruel fate, carelessness, lack of education, lack of prevention, lack of peace, weakness, impotence, irresponsibility, "wrecked" (popular expression meaning a person in trouble), a lot of freedom, no values, sin, loss of meaning, brothel, relationship with every person, taking responsibility.

In the third category, conviction imposed by Aids, the grouped words have a meaning of finality determined by the diagnosis of Aids, when one cannot imagine either a normal or a long life with the disease. These words showed that participants do not believe that there is a positive prognosis for the disease, or an adequate quality of life. The words were: over, ended life, came to an end, convicted, sentenced, end of life, end of the world, dies soon, die faster, death, there's no way, no way, "only Jesus" (popular expression indicating there is nothing to do to reverse/improve the situation), disillusioned, kills, dead, end of life, ends gradually, disgraces the family, fatal, end of line, end, dies slowly, "foot in the grave"(popular expression that refers to someone who is terminally ill, very close death), no chance, no life, "Only God" (popular expression that indicates there is nothing to do to reverse/improve the situation), divine punishment, without hope, motionless.

The fourth category, negative feelings about Aids, grouped words referring to the feelings participants have about the disease, and also how they believe that people with Aids feel about their diagnosis. It included words such as: agony, anguish, restlessness, scary, frightening, bad thing, disappointment, nasty, discouragement, despair, misery, destruction, horrible, horror, misery, insecurity, bad, fear, too bad, "muléstia" (popular expression which, in this context, refers to something very bad), disgusting, disgust, panic, thinks negatively, danger, dangerous, heavy (popular expression which, in this context, refers to something very bad), prejudice, rejection, bad, loneliness, fear, terrible, sad, sadness, regret, very ugly, depression, discouragement, despair, disillusionment, discouragement, contempt, destructive, pity, it is very sad, excluded, ugly, impotence, inability, unhappy, isolated, isolation, whining, nervousness, fear, loss, disturbs the mind, disturbing, bad, worry, bad feeling, suffering, shame, shaming, abandonment, anxiety, embarrassing, helplessness, grief, discrimination, painful, indifference, sin, shame, painful, the worst disease, rejection, tension, tragedy, everything that's bad.

The fifth and last category, positive feelings about Aids, grouped words for the support of people with Aids, care, and also the posture that HIV-positive people themselves could have when confronting this disease. The words grou- ped in this category were: help, support, companionship, care, hope, move on, embrace, love, faith, faith in God, self esteem, strength, willpower, perseverance, persistence, compassion.

\section{DISCUSSION}

With regard to sociodemographic characteristics, in the rural northeast, deficiencies in supply of and access to education, and a lack of jobs mean that many families face unemployment and live in miserable conditions. These conditions, when added to various factors such as age, sex, race/ethnicity, sexual orientation, and others, can constitute elements of vulnerability to a range of diseases, including Aids. In the present study, participants continue to have feelings of invulnerability and use unsafe sexual practices, such as not using condoms, although showing considerable concern about the Aids epidemic. It should be noted that the fact that they trust their partner leads to these people not using condoms in their sexual relations, leaving them in a more vulnerable situation in relationship to this disease and other STDs.

It is understood that care and health practices are influenced by the way people perceive and give meaning to their social world. The categories emerging from the analysis of free word-association varied in number of different words quoted, but, in general, showed a pejorative and stereotypical posture of respondents regarding Aids, which initially indicated the existence of negative representations about the disease. For example, there was a substantial expression of words related to fear of contamination, mortality of AIDS, and the effects on the body. Corroborating previous studies ${ }^{(7 ; 18-19)}$, these representations refer to the initial period of the spread of the epidemic, in that most cases (in particular "famous people") were disclosed through the media, showing the consequences of infection and its deadly nature. Thus, the rapid growth in the number of HIV-positive people led to this information being accepted as "truth" by society.

Despite technological advances currently achieved in the treatment of HIV/Aids, such as the introduction of antiretroviral therapy, the relationship of Aids with impending death is still central in the minds of people. Other representations were also perceived to refer to the beginning of the related epidemic, e.g., blaming and judgment of individuals who suffer from it. These representations bring the idea of Aids as a punishment for sin, especially when experienced by the "other", bringing out aspects related to sinful and depraved behavior, promiscuity and immorality. Considering contamination as a responsibility of the individual and "the other", this would happen due to a failure in moral behavior, rather than as an oversight or lack of prevention ${ }^{(19-20)}$. The approach, also focused on groups and risk behaviors, can lead to a certain "distance" regarding the disease, according to some authors, thereby contributing to feelings of invulnerability and the lack of adopting preventive behaviors such as condom use, especially when people are themselves in stable relationships.

Aids, as well as other disease processes, still seems to be a "disease of others", which impairs the management of 
prevention, and it is also related to the experience of people in their relationships and life contexts. This enables a variety of coping strategies in dealing with the disease, and also in the way to experience sexuality and incorporate preventive practices. In everyday life, sexuality is rarely considered or lived with attitudes and practices consistent with views and knowledge about Aids. It is necessary to understand the subject, always regarding his or her everyday scena$\operatorname{rios}^{(22)}$.

The assignment of Aids as an expression of sin also leads the respondents to have representations associated with feelings of fear and terror, as well as embarrassment or shame of being diagnosed with the disease. The sinner must be avoided and condemned, as he implies threats to society. Such a view is expressed in the prejudice and discrimination that are still painfully part of the experience of people living with HIV and are still entrenched in our society. The HIV-positive person is then doubly victimized: both by the disease and by the discriminatory attitudes that arise from it. These experiences can be observed in various aspects of the life of HIV-positive people, whether in the family, at work, or in other social relationships.

Although the representations about Aids found here mostly brings negative connotations, there were also expression of words trending towards possible changes in the vision. Embracing, support, hope and strength were some of them. Advances in treatment and increased survival of patients due to antiretroviral therapy for Aids brought the connotation of a chronic disease, allowing for actions to improve the quality of life of people living with $\mathrm{HIV}^{(17)}$. Thus, by the mid-2000s, representations including positive meanings and elements for coping with the disease started to be identified by emphasizing, e.g., living with the disease and a naturalization of the syndrome, understood as a chronic disease, such as diabetes and hypertension ${ }^{(17)}$. However, it is important to consider the most dominant representations found here, because these tend to point to the lack of knowledge that the inhabitants of Paraíba's rural towns have about AIDS. This indicates an inefficient performance of health services and existing prevention campaigns in these localities, showing an increased vulnerability of this population to illness from STDs/Aids.

In a way, the actions of prevention and health promotion through dissemination of information and campaigns at specific times, such as the carnival period, may neglect other demands and populations ${ }^{(23)}$. Representations relating to negative aspects of living with Aids are often spread due to a lack of clarification and information that people have, which is related to the programmatic dimension of vulnerability.

Understanding the vulnerability in the programmatic dimension requires analyzing the ways in which policies and institutions, especially those of health, education, welfare, social, cultural and justice, act as ways that reduce, reproduce or increase the subjects' vulnerability to conditions within their context ${ }^{(10)}$. The vulnerability dimensions should be recognized in the subjects' daily lives, whether through conversations in health services or social spaces where promotion and protection of the right to health, non-discrimination and social participation can be seen ${ }^{(10)}$.

The reduction of negative representations related to HIV/Aids requires the articulation of actions beyond the health spaces, contemplating a perspective based on human rights, expanding the actions for areas such as education, community services, social services, among others. This involves recognizing people as subjects of law, with a view to promoting citizenship.

\section{CONCLUSIONS}

Knowledge about the social representations of Aids, by people living in rural towns, enabled the identification of representations based on thematic categories which, although permeated by the beginning of the epidemic, are still present while guiding the conduct and interpretation of reality. Nevertheless, more than indicating the knowledge shared by a collective, these findings are related to the living contexts of these people and point to the existing gap between the availability of information and its incorporation into practice. Moderate concern existed about infection with the virus and, at the same time, there was low use of condoms during sexual intercourse.

The analysis of these results requires the consideration of aspects that go beyond the individual and his behavior, including the programmatic dimension of vulnerability, i.e., the structural aspects related to conditions of life that increase the chances of exposure of individuals and communities to the illness. The low educational and income level that characterized the socio-demographic profile of the participants are important factors, not only for access to information, but they also mediate how this information is properly incorporated. Moreover, in the northeastern rural context, certain settings in the health service, such as shortages of health professionals and lack of services aimed at testing and counseling regarding STDs hamper prevention even more. Social and educational aspects, as well as factors such as age, gender and sexual orientation, also contribute to vulnerability to Aids in this population.

It is from this macro-structural context that advances occur with the introduction of antiretroviral therapy, changing the status of Aids to the condition of a chronic disease, and at the same time also identifying representations of illness as being synonymous with impending death, immorality and promiscuity, as elements present in the daily communications of the participants. However, these results do not mean there is contradiction, but confirm the psychosocial nature of the theory of social representations, and also point to the dialectical dimension of the phenomenon that prevents any dichotomy between the individual and society.

Social representations are objects in the living conditions of the people, which show gaps in implementation of public policies, i.e., lack of knowledge on the subject identified through negative representations of Aids and/or people living with Aids suggests the need for educational campaigns and health services actions directed toward these demands. 
RESUMO

Nos 30 anos da pandemia da Aids no Brasil, reconhece-se o fenômeno da interiorização do vírus HIV como um desafio ao cuidado e às politicas de saúde atuais. Neste sentido, objetivou-se conhecer práticas sexuais e as representações sociais que residentes de cidades rurais têm acerca da doença. Participaram 789 pessoas, homens e mulheres, entre 18 e 90 anos de idade, residentes em 41 cidades com menos de 11.000 habitantes no estado da Paraíba/Brasil. Os dados foram coletados por um meio de um questionário e o teste de associação livre de palavras. Os resultados mostraram baixa preocupação com doença, percepção de invulnerabilidade à contaminação pelo HIV e o não uso do preservativo nas relações sexuais, sendo a confiança no parceiro o principal motivo relacionado. Também mostraram perdurar representações de natureza pejorativa e estereotipada, revelando que ainda perduram, no meio rural, crenças e representações referentes ao início da epidemia. A partir de tais achados, é possível apontar deficiências em termos de cuidados oferecidos pelos serviços de saúde nestas localidades, o que pode resultar em maiores vulnerabilidades dessa população ao adoecimento, havendo assim a necessidade da intensificação de campanhas de informação e intervenção.

\section{DESCRITORES}

Vulnerabilidade em saúde; população rural, síndrome de imunodeficiência adquirida.

\section{RESUMEN}

En los 30 años de pandemia de Sida en Brasil, se reconoce el fenómeno de la interiorización del virus VIH como un desafío al ciudadano y a las políticas de salud actuales. En este sentido, se objetivó conocer a prácticas sexuales y a las representaciones sociales que residentes en ciudades rurales tienen acerca de la enfermedad. Participaron 789 personas, hombres y mujeres, entre 18 y 90 años de edad, residentes en 41 ciudades con menos de 11.000 habitantes en el estado de Paraíba/ Brasil. Los datos fueran recolectados por medio de un cuestionario y el test de asociación libre de palabras. Los resultados demuestran una baja preocupación con la enfermedad, percepción de invulnerabilidad a la contaminación por el VIH y el no uso de preservativos en las relaciones sexuales, siendo la confianza en la pareja la principal razón relacionada. También mostraron perdurar representaciones de naturaleza peyorativa y estereotipada, revelando que aún perduran en el medio rural, creencias y representaciones referentes al inicio de la epidemia. A partir de tales hallados es posible apuntar deficiencias en términos de cuidados ofrecidos por los servicios de salud en estas localidades, lo que puede resultar en mayores vulnerabilidades de esa población a la enfermedad, habiendo así la necesidad de la intensificación de campañas de información e intervención.

\section{DESCRIPTORES}

Vulnerabilidad en salud ; población rural, síndrome de inmunodeficiencia adquirida.

\section{REFERENCES}

1. Greco DB. A epidemia da Aids: impacto social, científico, econômico e perspectivas. Estudos Avançados. 2008; (22):73-94.

2. Brito AM, Castilho EA, Szwarcwald, C L. AIDS e infecção pelo HIV no Brasil: uma epidemia multifacetada. Revista da sociedade Brasileira de Medicina Tropical. 2001; (34): 207-217.

3. Martins TA, Kerr LRFS, Kendall C, Mota RMS. Cenário epidemiológico da infecção pelo HIV e Aids no mundo. Revista Fisioterapia e Saúde Funcional. 2014; 3(1): 4-7.

4. García PJ, Bayer A Cárcamo CP. The Changing Face of HIV in Latin America and the Caribbean. Current HIV/AIDS reports. 2014. (11):146-157.

5. Brasil. Ministério da Saúde. Boletim Epidemiológico Aids e DST. Ano. 2. 2014.

6. Saldanha AA W.Vulnerabilidade e construções de enfrentamento da soropositividade ao HIV por mulheres infectadas em relacionamento estável. Tese de doutorado. Universidade de São Paulo. Ribeirão Preto: 2003.

7. Gir E, Canini SRMS, Prado MA, Carvalho MJ, Duarte G, Reis RK. A feminização da aids: conhecimento de mulheres soropositivas sobre a transmissão e prevenção do HIV-1. J bras Doenças Sex Transm. 2004; (16): 73-76.

8. Souza CC, Mata LRF, Azevedo A, Gomes, CRG, Cruz GECP, Toffano SEM. Interiorização do hiv/aids no brasil: um estudo epidemiológico. Revista Brasileira de Ciências da Saúde. 2012; (11): 25-30.

9. Ayres JRCM. Organização das Ações de Atenção à Saúde: modelos e práticas. Saúde e Sociedade. 2009; (18): 11-23.

10. Ayres JR, Paiva. V, França Jr. I. Conceitos e práticas de prevenção: da história natural da doença ao quadro da vulnerabilidade e direitos humanos. In.: Paiva V, Ayres JR Buchalla, CM. Vulnerabilidade e direitos humanos - prevenção e promoção da saúde: da doença a cidadania. Curitiba: Juruá, 2012.

11. Granjeiro A, Escuder M ML, Castilho E.A. Magnitude e tendência da epidemia de Aids em municípios brasileiros de 2002-2006. Revista de Saúde Pública, 2010.

12. Granjeiro A, Escuder MML, Castilho EA. A epidemia de AIDS no Brasil e as desigualdades regionais e de oferta de serviço. Caderno de Saúde Pública. 2010; 26(12): 2355-2367.

13. Saldanha AAW. Situações de Vulnerabilidade à Gravidez na Adolescência: Estilo de Vida e Comportamentos de Risco de Adolescentes Paraibanas. Relatório Final, Projeto Temático, Processo CNPq 551215/2007-0, Edital nº 22/2007- Saúde da Mulher. João Pessoa, PB, Universidade Federal da Paraíba, 2011.

14. Sampaio J, Santos RC, Callou JLL Souza B. B. Ele não Quer com Camisinha e eu Quero me Prevenir: exposição de adolescentes do sexo feminino às DST/aids no semi-árido nordestino. Revista Saúde e Sociedade. 2011; 20(1): 171-181.

15. Natividade JC, Camargo B V. Elementos caracterizadores das representações sociais da Aids para adultos. Temas em Psicologia. 2011; (19): 305-307.

16. Villarinho MV, Padilha MI, Berardinelli LMM, Borestein MS Meirelles BHS, Andrade SR. "Políticas públicas de saúde face à epidemia da AIDS e a assistência às pessoas com a doença". Rev Bras Enferm, Brasília, v. 66, p. 271-277, 2013. 
17. Vieira EWR. Acesso e utilização dos serviços de saúde de atenção primária em população rural do Município de Jequitinhonha, Minas Gerais. Dissertação de Mestrado. Universidade Federal de Minas Gerais. Belo Horizonte; 2010.

18. Oliveira DC. Construção e transformação das representações sociais da aids e implicações para os cuidados de saúde. Revista LatinoAmericana de Enfermagem. 2013; (21): 1-10.

19. Oltramari LC. Um Esboço sobre as Representações Sociais da AIDS nos Estudos Produzidos no Brasil. Cadernos de Pesquisa Interdisciplinar em Ciências Humanas. 2003; (45): 1-17.

20. Lobo MP. Vulnerabilidade ao HIV/AIDS: Representações sociais de idosos residentes em zona rural. Dissertação de mestrado. Universidade Estadual do Sudoeste da Bahia. 2011.

21. Alves MFP. Sexualidade e prevenção de DST/AIDS: representações sociais de homens rurais de um município da zona da mata pernambucana, Brasil. Cadernos de saúde pública. 2003; (19): 429-439.

22. Bardin. L. Análise de Conteúdo. Lisboa, Portugal, Edições 70, LDA. 2009.

23. Paiva V. Cenas da vida cotidiana: metodologia para compreender e reduzir a vulnerabilidade na perspectiva dos direitos humanos. In: Paiva V. Ayres JRCM, Buchalla CM. (Organizadores.). Vulnerabilidade e Direitos Humanos: prevenção e promoção da Saúde. Livro I. Curitiba: Juruá Editora, 2012b. p.165-208.

24. Garcia S, Souza FM. Vulnerabilidades ao HIV/aids no Contexto Brasileiro: iniquidades de gênero, raça e geração. Saúde Soc. $2010 ; 19$ supl 2: 9-20. 